\title{
The Substantia Nigra Conveys Target-Dependent Excitatory and Inhibitory Outputs from the Basal Ganglia to the Thalamus
}

\author{
Miklos Antal, Brandon M. Beneduce, and Wade G. Regehr \\ Department of Neurobiology, Harvard Medical School, Boston, Massachusetts 02115
}

The basal ganglia $(\mathrm{BG})$, which influence cortical activity via the thalamus, play a major role in motor activity, learning and memory, sensory processing, and many aspects of behavior. The substantia nigra (SN) consists of GABAergic neurons of the pars reticulata that inhibit thalamic neurons and provide the primary output of the $B G$, and dopaminergic neurons of the pars compacta that modulate thalamic excitability. Little is known about the functional properties of the $\mathrm{SN} \rightarrow$ thalamus synapses, and anatomical characterization has been controversial. Here we use a combination of anatomical, electrophysiological, genetic, and optogenetic approaches to re-examine these synaptic connections in mice. We find that neurons in the $\mathrm{SN}$ inhibit neurons in the ventroposterolateral nucleus of the thalamus via GABAergic synapses, excite neurons in the thalamic nucleus reticularis, and both excite and inhibit neurons within the posterior nucleus group. Glutamatergic SN neurons express the vesicular glutamate receptor transporter vGluT2 and receive inhibitory synapses from striatal neurons, and many also express tyrosine hydroxylase, a marker of dopaminergic neurons. Thus, in addition to providing inhibitory outputs, which is consistent with the canonical circuit, the SN provides glutamatergic outputs that differentially target thalamic nuclei. This suggests that an increase in the activity of glutamatergic neurons in the SN allows the BG to directly excite neurons in specific thalamic nuclei. Elucidating an excitatory connection between the BG and the thalamus provides new insights into how the BG regulate thalamic activity, and has important implications for understanding BG function in health and disease.

Key words: circuitry; substantia nigra; vGluT2

\section{Introduction}

The basal ganglia (BG) are crucial to motor tasks, movement initiation, learning, memory, arousal, reward reinforcement, sensory processing, and numerous cognitive and emotional processes (Smith and Bolam, 1990; Joel and Weiner, 1994; Hauber, 1998; Bolam et al., 2000; Silkis, 2001; Packard and Knowlton, 2002; Sridharan et al., 2006; Deniau et al., 2007; Schmidt et al., 2013). BG dysfunction is implicated in Huntington's and Parkinson's diseases, drug addiction, and obsessive-compulsive disorder (DeLong and Wichmann, 2007; Wichmann et al., 2007; Grueter et al., 2012; Pascoli et al., 2012). Although remarkable progress has been made in clarifying BG circuitry (Gong et al., 2003, 2007; Bateup et al., 2010; Gittis et al., 2010; Jin and Costa, 2010; Kravitz et al., 2010; Witten et al., 2010; Adamantidis et al., 2011), relatively little is known about the outputs from the BG to

\footnotetext{
Received Jan. 17, 2014; revised April 30, 2014; accepted May 2, 2014.

Author contributions: M.A. and W.G.R. designed research;M.A. and B.B. performed research;M.A. analyzed data; M.A. and W.G.R. wrote the paper.

This study was supported by National Institutes of Health Grant NIH R01NS032405 (to W.G.R.) and by a Lefler Postdoctoral Fellowship (M.A.). We thank the Neurobiology Imaging Facility (supported by NINDS P30 Core Center Grant NS072030) for consultation and instrument availability. We thank Nicolas Tritsch and members of the Regehr laboratory for valuable constructive comments and suggestions; and Kimberly McDaniels and Hannah Goulart for laboratory technical assistance.

Correspondence should be addressed to Wade G. Regehr, Department of Neurobiology, Harvard Medical School, Goldenson Building, Room 308, 220 Longwood Avenue, Boston, MA 02115. E-mail: wade_regehr@hms.harvard.edu. DOI:10.1523/JNEUROSC1.0236-14.2014

Copyright $\odot 2014$ the authors $\quad 0270-6474 / 14 / 348032-11 \$ 15.00 / 0$
}

the thalamus (Di Chiara et al., 1979; Kilpatrick et al., 1980; Rajakumar et al., 1994; Yung et al., 1998).

Several hypotheses have been advanced to account for how the BG influence the thalamus, the cortex, and ultimately behavior. According to recognized circuitry, GABAergic neurons in the substantia nigra pars reticulata (SNR) provide the primary output of the BG. The SN also contains dopaminergic neurons in the pars compacta (SNC) that modulate synapses and excitability in the thalamus (Lavin and Grace, 1998; Sánchez-González et al., 2005; Yagüe et al., 2013). SNR neurons fire spontaneously at $30-60 \mathrm{~Hz}$, and the prevailing view is that they tonically inhibit thalamic neurons (Kilpatrick et al., 1980; MacLeod et al., 1980; Chevalier and Deniau, 1984, 1990; Chevalier et al., 1985; Deniau et al., 2007; Berényi et al., 2009). Suppression of SNR activity disinhibits the thalamus, and thereby elevates thalamic and cortical activity (Chevalier and Deniau, 1984, 1990; Chevalier et al., 1985; Deniau et al., 2007). In the birdsong system, BG activity produces precisely timed rebound spikes in thalamic neurons (Doupe et al., 2005; Person and Perkel, 2005; Leblois et al., 2009). It has been shown however, that SN neurons are not exclusively GABAergic or dopaminergic (Oertel and Mugnaini, 1984; Deutch et al., 1986; Gould and Butcher, 1986; Kha et al., 2001); some express the vesicular glutamate transporter vGluT2, suggesting that they release glutamate (Yamaguchi et al., 2013). However, little is known about the properties of these vGluT2positive cells. 
Here, we examined the properties of synapses made by $\mathrm{SN}$ onto thalamic neurons in the following three regions: the ventroposterolateral nucleus (VPL), the nucleus reticularis (nRT), and the posterior nucleus group [i.e., posterior thalamus (PTh)]. We find that the $\mathrm{SN}$ influences each of these regions in different ways: VPL neurons are inhibited in a manner that is consistent with the canonical circuit, but nRT neurons are excited, and PTh neurons receive both GABAergic and glutamatergic innervation. In addition, many vGluT2-positive neurons also express tyrosine hydroxylase (TH), indicating that they are also dopaminergic. Thus, nigral thalamic efferents deviate markedly from the prevailing view, as their function extends beyond simple inhibition and disinhibition of thalamic neurons.

\section{Materials and Methods}

Transgenic animals: viral and retrograde bead injections. Animals with Slc17 $6^{\text {tm2(cre)Lowl } / J ~ g e n e t i c ~ b a c k g r o u n d ~(v G l u T 2-C r e ~ m i c e ; ~ V o n g ~ e t ~ a l ., ~}$ 2011) and with B6;129-Hprt ${ }^{\text {tm2(CMV-tdTomato)Nat/J genetic background }}$ (tdTomato mice; stock \#021428, The Jackson Laboratory) were bred together to obtain offspring carrying both Cre and floxed tdTomato alleles (vGluT2-Cre::tdTomato), allowing visual identification of vGluT2-positive neurons in slice preparations based on red tdTomato fluorescence. vGluT2 has been widely used as specific marker of glutamatergic neurotransmission to determine functionally distinct neuron populations (Fremeau et al., 2001). Crosses of mice with vGluT2-Cre::tdTomato and GAD67::GFP genetic backgrounds (Tamamaki et al., 2003) were also generated, yielding a mouse line carrying both tdTomato and GFP genes in distinct, vGluT2-positive and GAD67-positive cell populations, respectively (vGluT2-Cre::tdTomato/GAD67::GFP). To study vGluT2-specific SN outputs to thalamus, vGluT2-Cre mice were used. Mice of either sex were used in these studies. All animal handling and procedures abided by the guidelines of the Harvard Medical Area Standing Committee on Animals.

Recombinant adeno-associated viruses (AAVs) carrying fusion genes for channelrhodopsin-2 (ChR2) and fluorescent reporter genes were injected into SN of transgenic mice in vivo, between postnatal days 14 and 18 using a stereotaxic device. Viral vectors were provided by the University of Pennsylvania Vector Core: AAV1.CAG.hChR2(H134R)-mCherry.WPRE. SV40, AAV1.hSyn.hChR2(H134R)-eYFP.WPRE.hGH, and AAV9.EF1a. DIO.hChR2(H134R)-eYFP.WPRE.hGH. Injection volumes were between 40 and $100 \mathrm{nl}$. After allowing 3-4 weeks for ChR2 expression, acute sagittal brain slices were cut for in vitro recording and stimulation. In experiments, where striatal inputs onto vGluT2-positive SN neurons were studied, AAVs were injected into striatum, and whole-cell recordings were later performed from vGluT2-positive neurons within the SN. Injection coordinates for SN injections were as follows (using the median sagittal line at lambda as reference point; in $\mathrm{mm}$ ): 1 rostral, 1.3 lateral, and 4.55 depth. Injection coordinates for striatum injections were as follows (in mm): 4.7 rostral, 1.35 lateral, and 3.3 depth.

We used Green Lumafluor Retrobeads IX (Lumafluor) to perform fluorescent retrograde tract tracing. These latex nanobeads are $0.02-0.2$ $\mu \mathrm{m}$ in diameter, and contain a green fluorescent dye with peak excitation and emission wavelengths at 460 and $505 \mathrm{~nm}$, respectively. An array of previous studies has shown that when this tracer is injected, there is little diffusion observed, no cytotoxicity or phototoxicity, and strong labeling, which persists up to 10 weeks (Katz et al., 1984; Eyre et al., 2008; Lammel et al., 2008; Daubaras et al., 2014). Injection coordinates for nRT injections were as follows (using the median sagittal line at lambda as reference point; in $\mathrm{mm}$ ): 3.25 rostral, 1.75 lateral, and 3.25 depth. Injection coordinates for VPL injections were as follows: 2.9 rostral, 1.55 lateral, and 3.55 depth. Injection coordinates for PTh injections: 2.3 rostral, 1.1 lateral, and 2.9 depth.

Slice preparation. Mice (35-42 d old; C57BL/J6 described above and in Results) were deeply anesthetized with isoflurane; their brains were then quickly removed and placed in ice-cold oxygenated (95\% oxygen $/ 5 \%$ $\mathrm{CO}_{2}$ ) solution consisting of the following (in $\mathrm{mm}$ ): $130 \mathrm{~K}$-gluconate, 15 $\mathrm{KCl}, 0.05$ EGTA, $20 \mathrm{HEPES}$, and 25 glucose, $\mathrm{pH}$ 7.4, with $\mathrm{NaOH}$. Acute sagittal slices (250 $\mu \mathrm{m}$ thick) were prepared from the injected hemispheres. Slices were then stored in a submerged equilibrium chamber with artificial CSF equilibrated with $95 \% \mathrm{O}_{2}$ and $5 \% \mathrm{CO}_{2}$, consisting of the following (in mM): $125 \mathrm{NaCl}, 26 \mathrm{NaHCO}_{3}, 1.25 \mathrm{NaH}_{2} \mathrm{PO}_{4}, 2.5 \mathrm{KCl}, 1$ $\mathrm{MgCl}_{2}, 2 \mathrm{CaCl}_{2}$, and 25 glucose, $\mathrm{pH} 7.3$, osmolarity 310. Slices were incubated initially at $32^{\circ} \mathrm{C}$ for $15 \mathrm{~min}$ and then at room temperature. After $0.5-1 \mathrm{~h}$ of recovery, brain slices were placed in the recording chamber mounted on an Olympus BX51WI microscope equipped with differential interference contrast (DIC) and fluorescence capabilities. The temperature in the recording chamber was kept near $34^{\circ} \mathrm{C}$ using an inline heating device (Warner Instruments). The tissue was continuously superfused with oxygenated ACSF at a flow rate of $\sim 5 \mathrm{ml} / \mathrm{min}$.

Electrophysiological recordings. The inhibitory interneurons within the nRT were identified by selective GFP expression in GAD67::GFP transgenic animals (Tamamaki et al., 2003), and C57BL/J6 animals were used for some of the VPL and PTh cell recordings, green fluorescent proteinexpressing cells, and red fluorescent ChR2 fusion protein-expressing SN axons were identified using appropriate fluorescence filters and then approached under DIC

Whole-cell voltage-clamp recordings were performed by using 2-3.5 $\mathrm{M} \Omega$ borosilicate glass pipettes pulled with a horizontal puller (Sutter Instruments) and filled with an intracellular solution that contained the following (in mM): 140 Cs-methanesulfonate, 15 HEPES, 0.5 EGTA, 2 TEA-Cl, 2 MgATP, 0.3 NaGTP, 10 phosphocreatine-tris2, and 2 QX $314-\mathrm{Cl}$. pH was adjusted to 7.2 with $\mathrm{CsOH}$. Membrane potentials were not corrected for the liquid-junction potential. Access resistance was continuously monitored throughout the experiments, and only those cells with stable access resistance (changes $<10 \%$ ) were used for analysis. Neurotransmitter receptor antagonists (all from Tocris Bioscience) were applied by bath perfusion: picrotoxin $(20 \mu \mathrm{M}), \mathrm{NBQX}(5 \mu \mathrm{M})$, and 3- $((R)-$ 2-carboxypiperazin-4-yl)-propyl-1-phosphonic acid (R-CPP; $5 \mu \mathrm{M})$.

Recordings were performed with a 700B Axoclamp amplifier (Molecular Devices) and were controlled with custom software written in Igor Pro 6.0 (generously provided by Mathew Xu-Friedman, SUNY Buffalo, Buffalo, NY).

Data analysis and statistical comparisons. All data analyses were performed using software custom written in Igor Pro 6.0 (WaveMetrics). All data are expressed as the mean \pm SEM.

Selective ChR2-mediated stimulation of striatal and nigral efferents. To assess responses to optical stimulation of SN pathways, whole-cell recordings were made from $\mathrm{nRT}$ and thalamic neurons, and responses to blue laser stimuli $(473 \mathrm{~nm})$ were measured in voltage-clamp. The laser was usually focused as a $\sim 130-\mu \mathrm{m}$-diameter spot through a $63 \times$ waterimmersion objective. Maximum total laser power density at the focal plane of the slice was $\sim 300 \mathrm{~mW} / \mathrm{mm}^{2}$. For synaptic stimulation, $0.5-1$ $\mathrm{ms}$ flashes were delivered directly over the recorded soma.

We initially injected ChR2-mCherry AAV into SN and continued in later experiments with other above-mentioned AAV constructs. When injections were successfully targeted, mCherry labeling was found throughout the $\mathrm{SN}$ near the injection site, and in axons in multiple brain regions (see Results). Importantly, brightly labeled bundles of SN axonal arbors were observed in the VPL, nRT, and PTh (Fig. 1; see also Fig. 3; $n>50$ injections). Laser stimulation of ChR2-expressing SN axons evoked current responses recorded in voltage-clamp, as described above.

In all experiments, the minimal light intensity necessary to activate $\mathrm{SN}$ axons was first determined by sequentially stimulating the fluorescent axons containing ChR2 at progressively higher laser power densities (from 0 to $\sim 300 \mathrm{~mW} / \mathrm{mm}^{2}$, every $30 \mathrm{~s}$ ) while recording either from $\mathrm{nRT}$ interneurons or VPL and PTh cells. With increasing intensities, IPSCs and EPSCs increased in amplitude, indicating the recruitment of additional axons. Once the threshold light intensity was determined, the stimulus intensity was kept at midway between maximum intensity and threshold (typically, $100 \mathrm{~mW} / \mathrm{mm}^{2}$ for $1 \mathrm{~ms}$ ).

Epifluorescent and confocal microscopy. Postnatal day 35 (P35) to P45 mice were deeply anesthetized with isoflurane and a ketamine/xylazine mixture, and were perfused transcardially with $4 \%$ paraformaldehyde in $0.1 \mathrm{M}$ sodium phosphate buffer (Sigma-Aldrich). Brains were post-fixed, washed in PBS, and stored at $4^{\circ} \mathrm{C}$ for 1-3 days until further processing. Injected hemispheres were then sectioned at $50 \mu \mathrm{m}$ sagitally ( $\mathrm{Vi}_{-}$ 

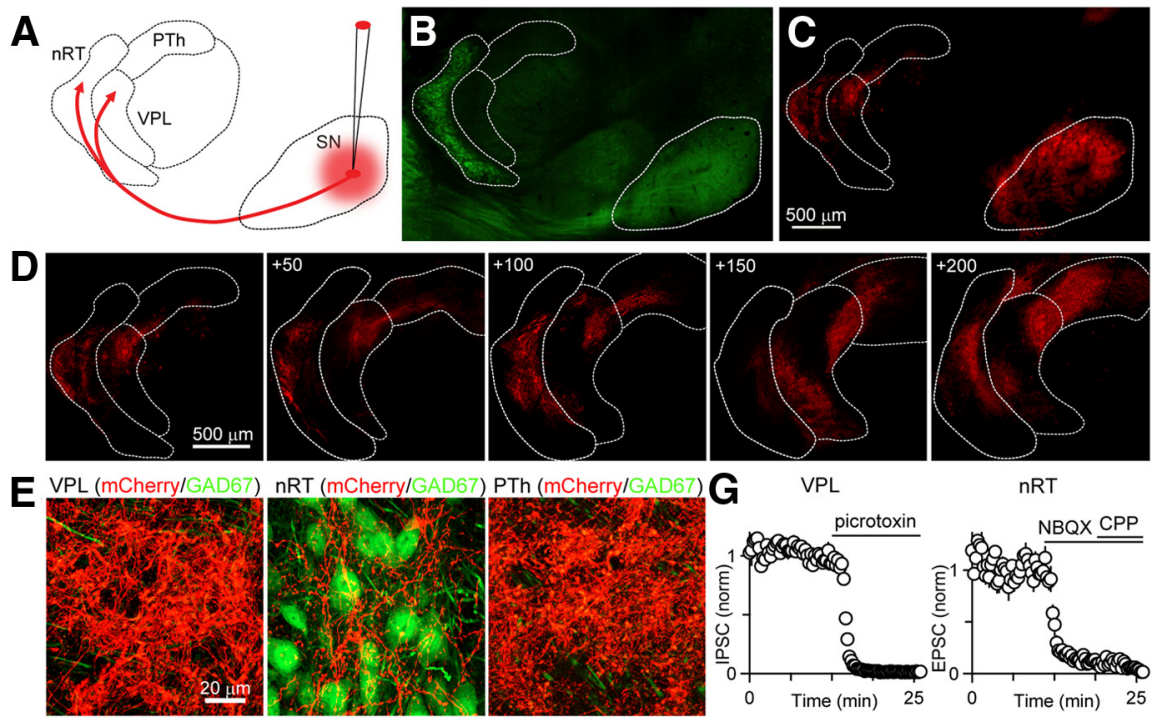

$\mathrm{nRT}$

F
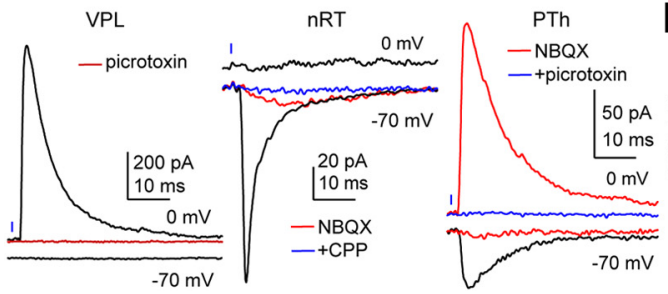

$\mathbf{H}_{1000}$

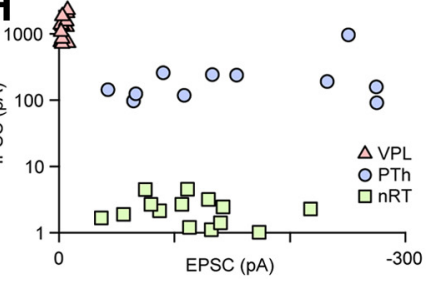

Figure 1. The SN provides both excitatory and inhibitory connections to the thalamic nuclei in a target-dependent manner. A, Schematic showing AAV injection to express ChR2-mCherry in SN neurons cells. Thalamic regions are labeled nRT, VPL, and PTh. $\boldsymbol{B}$, The injection was performed in a GAD67-GFP mouse, in which inhibitory neurons are labeled in green. The SN and the nRT, which contain primarily GABAergic neurons, are readily identified. $\boldsymbol{C}$, mCherry fluorescence shows prominent expression in $\mathrm{SN}$ cell bodies in the $S N$ and fibers in the thalamus. $\boldsymbol{D}$, Fiber labeling within the thalamus is shown for multiple consecutive sections, with the first panel corresponding to plate 11. Coordinates indicate steps, in micrometers, toward midline. $\boldsymbol{E}$, High-power images of red and green fluorescence show the labeled fibers (mCherry) and GABAergic neurons (green in GAD67-GFP mice) within different thalamic regions. $F$, Representative light-evoked responses are shown for the different nuclei. Glutamate-mediated currents were recorded at $-70 \mathrm{mV}$, while $\mathrm{GABA}_{\mathrm{A}}$-mediated responses were studied at $0 \mathrm{mV}$. In the VPL, no excitatory response was observed, but an inhibitory current at $0 \mathrm{mV}$ was eliminated with a $\mathrm{GABA}_{\mathrm{A}} \mathrm{R}$ antagonist (red, picrotoxin). In the $\mathrm{nRT}$, no excitatory component was observed, but an excitatory component was observed that greatly attenuated to an AMPAR antagonist (red, NBQX) and was eliminated by the subsequent addition of an NMDARantagonist (blue, (PP). In the PTh, an excitatory component was observed (black, -70 $\mathrm{mV}$ ) that was almost eliminated by NBQX (red). A light-evoked response was also observed at $0 \mathrm{mV}$ that was unaffected by NBQX (red), indicating a direct, monosynaptic inhibitory response, which was eliminated by picrotoxin. G, Summary of pharmacological characterization of light-evoked responses using a GABA $A_{A} R$ antagonist (picrotoxin), an AMPAR antagonist (NBQX), and an NMDAR antagonist $(R-C P)$. $\boldsymbol{H}$, Summary of the amplitudes of light-evoked IPSCS and EPSCS in different thalamic regions.

bratome). Free-floating sections were then incubated in blocking solution [PBS plus $0.5 \%$ Triton X-100 (PBST) plus 10\% normal goat serum] for $1 \mathrm{~h}$ at room temperature. Slices were incubated with primary antibodies (monoclonal tyrosine hydroxylase antibodies; catalog \#22941, ImmunoStar) in PBST overnight at $4^{\circ} \mathrm{C}$, followed by incubation with secondary antibodies in PBST overnight at $4^{\circ} \mathrm{C}$. Slices were mounted to Superfrost glass slides (VWR) and air dried for $30 \mathrm{~min}$. Following application of DAPI-containing Prolong anti-fade medium (Invitrogen), slices were covered with a top glass coverslip (VWR) and allowed to dry for $24 \mathrm{~h}$ before imaging. Antibodies were used at a dilution of 1:1000.

Brain hemisphere sections were identified based on comparisons among 21 sagittal plates from the Allen Brain Atlas (version 2, 2011) and epifluorescent transgene signals from sections obtained by our slicing methodology. Coordinates in figure panels indicate steps (in micrometers) toward the midline. Whole sections were imaged with an Olympus VS110 slide-scanning microscope. High-resolution images of regions of interest were subsequently acquired with a Zeiss LSM 510 META confocal microscope (Harvard NeuroDiscovery Center) using a Planapochromat $63 \times, 1.4$ numerical aperture, oil lens. Appropriate excitation and emission filters were used to visualize GFP, mCherry, tdTomato, and yellow fluorescent protein (YFP). Single optical sections of $1024 \times 1024$ (Kalman average of 15 scans) were obtained sequentially for the different channels.

\section{Results}

We used an optogenetic approach to study outputs from the SN to the thalamus, because selective electrical activation of $\mathrm{SN}$ ax- ons is impractical due to the multiple sources of afferents to thalamic neurons (Cebrián et al., 2005). Stereotaxic injections were used to introduce AAV and express ChR2-mCherry in the SN (Fig. 1A). GAD67::GFP transgenic mice were used in which GABAergic neurons within the $\mathrm{nRT}$ and the $\mathrm{SN}$ are labeled (Fig. $1 B)$. Red mCherry fluorescence was apparent at the injection sites in the $\mathrm{SN}$, and in projections within the thalamus. The pattern of labeled fibers from a typical injection is shown for successive sections (Fig. 1C,D). High-power confocal images reveal dense fiber labeling within the VPL, nRT, and the PTh (Fig. 1E).

Activation of SN fibers with brief light flashes $(0.5-1 \mathrm{~ms})$ evoked synaptic responses in the VPL, nRT, and the PTh (Fig. 1 $F$ ). In these experiments, voltage-clamp recordings were made using an internal solution in which the $\mathrm{Cl}^{-}$concentration was set such that the $\mathrm{GABA}_{\mathrm{A}}$-mediated response reversed at $-70 \mathrm{mV}$, whereas synaptic currents mediated by AMPA and NMDA receptors reversed at $0 \mathrm{mV}$. Thus, glutamatergic responses could be studied in isolation at $-70 \mathrm{mV}$, and $\mathrm{GABA}_{\mathrm{A}}$-mediated currents could be studied at $0 \mathrm{mV}$. In the VPL (Fig. $1 F$, left), no excitatory response was observed when the cell was held at $-70 \mathrm{mV}$, while an inhibitory current at $0 \mathrm{mV}$ was eliminated by a $\mathrm{GABA}_{\mathrm{A}}$ receptor $\left(\mathrm{GABA}_{\mathrm{A}} \mathrm{R}\right)$ antagonist (red). Picrotoxin reduced the IPSC amplitude evoked in the VPL to $0.8 \pm 0.1 \%(n=8)$ of initial values (Fig. $1 G$, left). In the nRT (Fig. $1 F$, middle), no inhibitory 

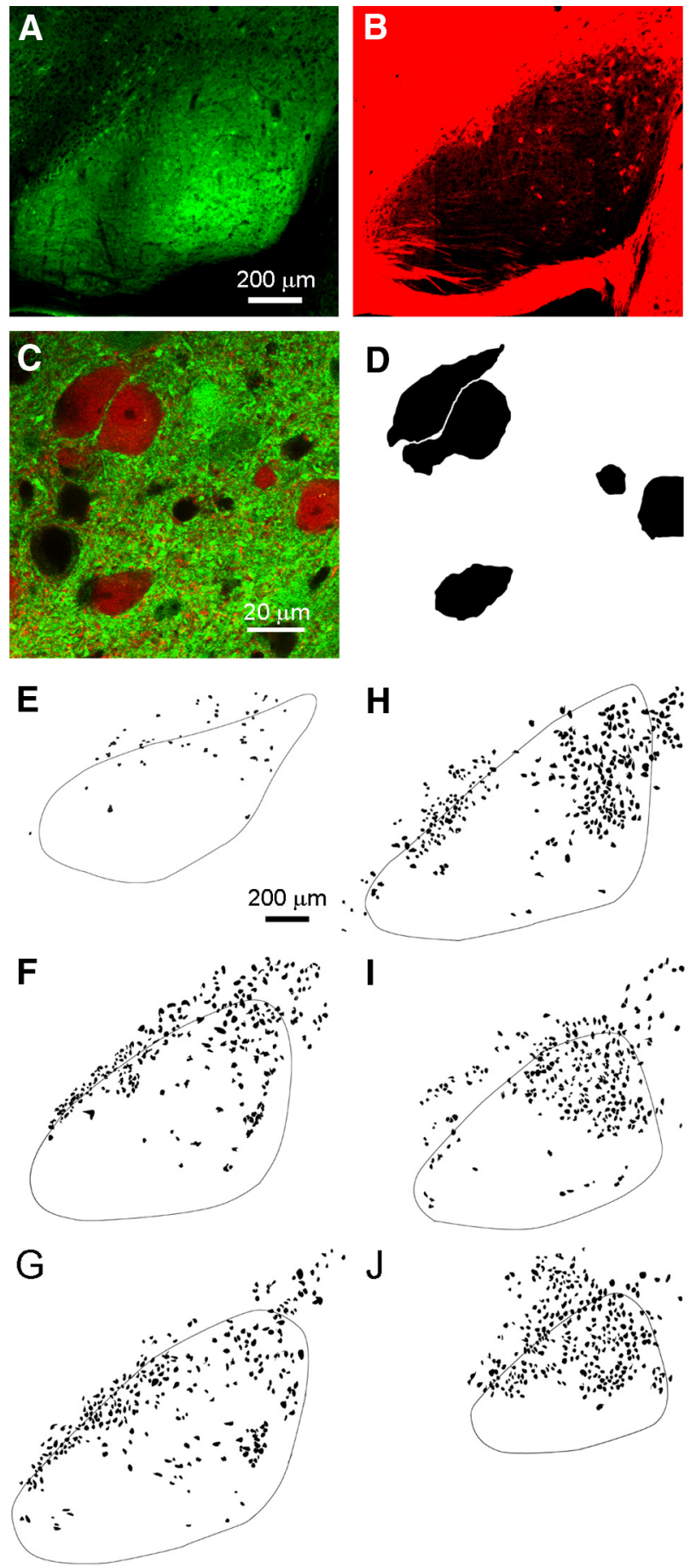

Figure 2. GABAergic and glutamatergic neurons in the substantia nigra form two nonoverlapping populations as identified in GAD67::GFP/vGluT2::tdTomato transgenic mice. $\boldsymbol{A}$, Low-magnification view of widespread green GFP epifluorescent signal due to the abundant presence of GABAergic somata and processes within the $\mathrm{SN}$. This sagittal slice was taken from a mouse line expressing both tdTomato and GFP genes in vGluT2-positive and GAD67-positive cell populations, respectively (vGluT2-Cre::tdTomato/GAD67::GFP). B, A sparser and more peripheral but substantial red tdTomato epifluorescent signal is exhibited in the same slice by vGluT2-positive neurons within the SN. C, Confocal merged image of green and red fluorescence demonstrating the mutual exclusivity of the GABAergic and glutamatergic neuron populations. D, vGluT2-positive neurons were identified by red fluorescence. Representative example of the schematization process during which the glutamatergic cell bodies were colored black and the background removed. Neurons expressing both vGluT2 (red) and GAD67 (green) were not observed. $\boldsymbol{E}-\boldsymbol{J}$, The location of vGluT2-positive neurons in SN, identified as in $\boldsymbol{D}$, is shown for six sections from the same hemisphere. The representative schematized images of $S \mathrm{~N}$ slice preparations were taken at lateral $(\boldsymbol{A})$, intermediate $(\boldsymbol{F}-\boldsymbol{H})$, and medial $(\boldsymbol{I}, \boldsymbol{J})$ sagittal planes.
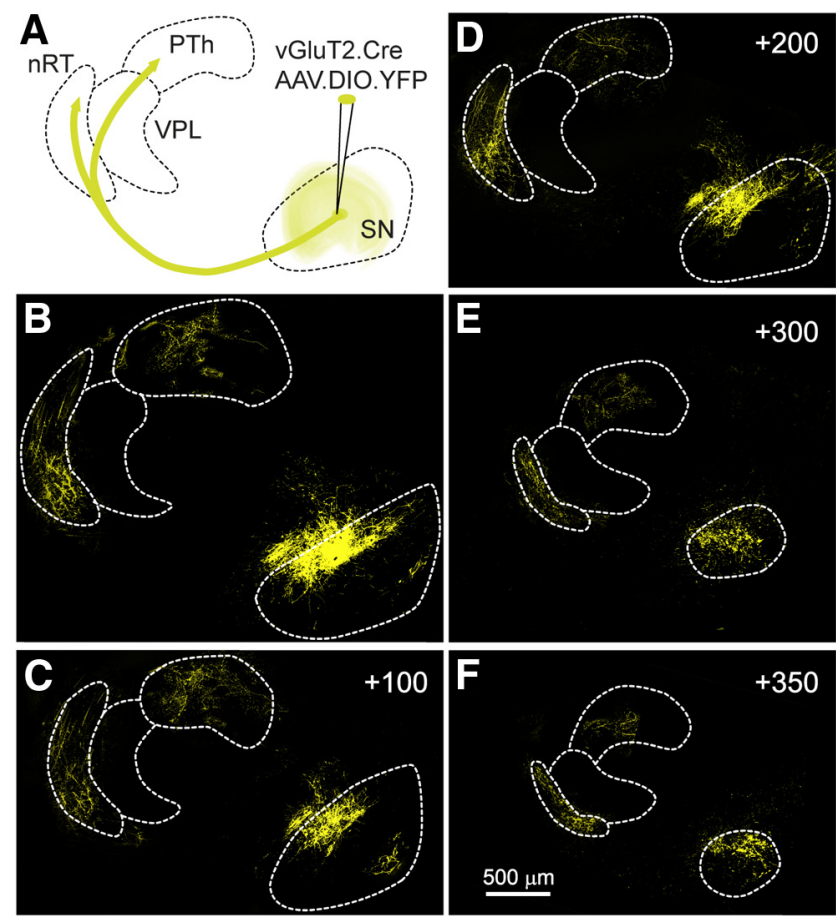

SN
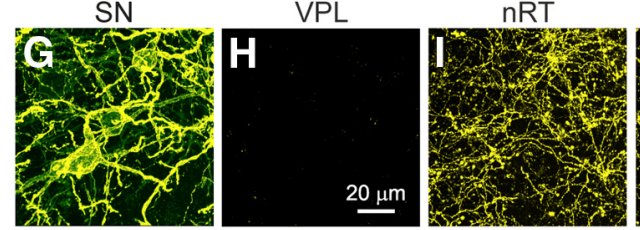

PTh

Figure 3. Glutamatergic neurons in the substantia nigra send projections to the $\mathrm{nRT}$ and the PTh, but not the VPL. $\boldsymbol{A}$, Schematic showing the conditional viral expression and the injection site in a vGluT2-Cre mouse. $\boldsymbol{B}-\boldsymbol{F}$, Successive sections showing the YFP labeling in the SN and thalamus, with the first panel corresponding to plate 13. Coordinates indicate steps, in micrometers, toward the midline. $\mathbf{G}-\boldsymbol{J}$, High-power images of the labeling observed in the SN and in different thalamic regions.

current was observed at $0 \mathrm{mV}$, but an excitatory current was observed at $-70 \mathrm{mV}$ that was nearly abolished by the AMPAR antagonist NBQX (reduced to $9 \pm 1 \%$ of initial values, $n=7$; red) and eliminated by the subsequent addition of an NMDAR antagonist (reduced to $1.0 \pm 0.2 \%$ of initial values, $n=8$; blue). In the PTh (Fig. $1 F$, right), an excitatory component was observed at $-70 \mathrm{mV}$ that was strongly attenuated by an AMPAR antagonist (red). On average, the AMPAR antagonist reduced the EPSCs to $5 \pm 2 \%(n=5)$ of initial values (Fig. $1 G$, right). A light-evoked response was also observed at $0 \mathrm{mV}$ that was unaffected by NBQX ( red), indicating that it was not the result of activating glutamatergic fibers that in turn recruited disynaptic inhibitory input. This IPSC was eliminated by a $\mathrm{GABA}_{\mathrm{A}} \mathrm{R}$ antagonist $(2.0 \pm 0.8 \%$ of initial IPSC amplitude, $n=5$ ).

A summary of the light-evoked synaptic currents revealed clear target-specific differences in the properties of synapses made by SN in different thalamic regions (Fig. $1 H$ ). In the VPL, inhibitory responses were consistently large $(1340 \pm 140 \mathrm{pA}$ at 0 $\mathrm{mV}, n=13)$, while excitatory responses were negligible $(-4.3 \pm$ $0.7 \mathrm{pA}$ ) at $-70 \mathrm{mV}$, indicating that the responses were exclusively inhibitory. In the nRT, excitatory responses were large $(-117 \pm$ $13 \mathrm{pA}$ at $-70 \mathrm{mV}, n=14)$, but the response at $0 \mathrm{mV}$ was exceedingly small $(2.1 \pm 0.3 \mathrm{pA})$, indicating that the responses were exclusively excitatory. Meanwhile, all PTh cells received synaptic input with both inhibitory and excitatory components ( $240 \pm 75$ $\mathrm{pA}$ at $0 \mathrm{mV} ;-150 \pm 27 \mathrm{pA}$ at $-70 \mathrm{mV} ; n=11)$. 

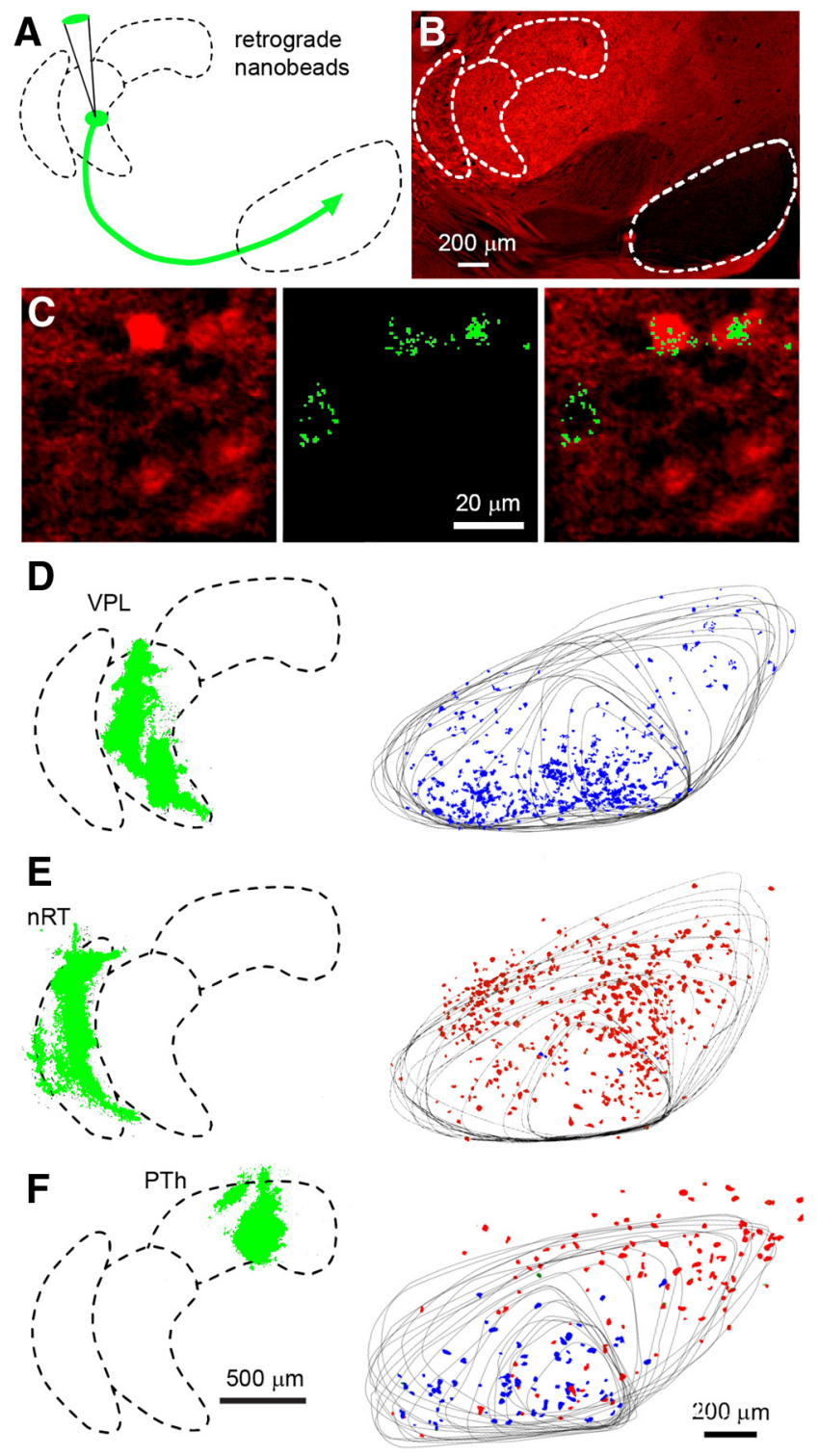

Figure 4. Retrograde labeling of SN neurons following nanobead injection into thalamic nuclei. $\boldsymbol{A}$, Schematic showing the injection of nanobeads into the thalamus of a vGluT2-Cre::tdTomato mouse. $\boldsymbol{B}$, The injections were performed in vGluT2-Cre::tdTomato mice in which vGluT2-positive neurons are labeled in red. Distinct regions exhibiting differential vGluT2 density are readily identified. $C$, High-power image in the SN in which neurons that express vGluT2 are red (left), retrogradely labeled neurons show characteristic punctate green fluorescence (middle), and the merged image shows that, following this injection into the PTh, one non-glutamatergic and two glutamatergic neurons were labeled. $\boldsymbol{D}$, Shows an experiment in which beads were injected into the VPL, with the injection site shown as a Z-stack determined from 17 sections (left, green). Twenty-one sections were used to determine the location of bead-labeled neurons in the SN, with the outline of the SN shown for all of the sections, and bead-labeled neurons were color coded, with red indicating vGluT2-positive neurons and blue indicating vGluT2-negative neurons. $\boldsymbol{E}$, Example of retrograde labeling following bead injection into the $n R T$. $\boldsymbol{F}$, Example of retrograde labeling following bead injection in the PTh.

Thus, our functional studies reveal a glutamatergic output from the SN to the thalamus that targets the PTh and nRT, but not the VPL. Previous studies used the presence of vesicular glutamate transporters to identify glutamatergic neurons in the SN and found that vGluT2 was present in the SN, but not vGluT1 or vGluT3 (Yamaguchi et al., 2013). This suggests that the vGuT2Cre mice (Vong et al., 2011) could be useful in the study of glutamatergic neurons in the SN. Crossing vGuT2-Cre mice with a conditional tdTomato mouse line yields a mouse line in which vGlut2-positive cells are red. Similarly, GABAergic neurons are green in GAD67::GFP mice. Through appropriate crosses, we obtained a mouse line in which vGluT2-positive cells are labeled in red and GAD67::GFP cells are labeled in green. Most of the neurons in the $\mathrm{SN}$ are GABAergic (Fig. 2A). The $\mathrm{SN}$ is surrounded by glutamatergic fibers and neurons, and, as shown previously (Yamaguchi et al., 2013), the SN contains vGluT2positive neurons, but they are much less prevalent than GABAergic neurons (Fig. 2B). High-power images of the SN allowed identification of GFP and tdTomato expression in cell bodies. Overlap between red- and green-labeled cell bodies was not observed (Fig. 2C). As shown in a representative example slice, vGluT2-positive neurons were readily identified (Fig. 2C,D). To get a sense of the location of vGluT2-positive neurons in the $\mathrm{SN}$, we imaged a series of sections and used tdTomato epifluorescence to identify vGluT2-positive neurons (Fig. 2E-J), as demonstrated in Figure 2D. vGluT2-positive neurons were present in each section, they were intermingled with GABAergic neurons rather than being located in a well defined clusters, and they tended to be located at a higher density in the dorsal region of the SN.

To further test for the presence of these glutamatergic projections, we injected a conditional AAV construct into vGluT2-Cre animals to label glutamatergic neurons in the SN with YFP $(n=$ 6, Fig. $3 A$ ). A subset of neurons was labeled at the injection site, and projections were apparent in the thalamus (Fig. $3 B-F$ ). Prominent fiber labeling was observed in the nRT and the PTh, but not in the VPL. High-power views from these regions confirmed that cell bodies and neuronal processes were labeled in the SN (Fig. 3G), fibers and boutons were apparent in the nRT (Fig. 3I) and the PTh (Fig. 3J), and no labeling was apparent in the VPL (Fig. $3 H$ ). These findings support our functional studies and indicate that there are vGluT2-positive neurons in the SN that send efferents to the nRT and the PTh, but not to the VPL.

Our findings predict that retrograde labeling of SN neurons that project to the VPL, nRT, and PTh should label, respectively, GABAergic neurons, glutamatergic neurons, and both GABAergic and glutamatergic neurons. We tested this by injecting fluorescent nanobeads into distinct regions of the thalamus in vGluT2-Cre::tdTomato mice (Fig. 4A). In these animals, vGluT2-positive cells are red and other cells show an absence of fluorescence (Fig. $4 B$ ). The beads are taken up by axon terminals and then retrogradely transported to the cell bodies of projection neurons (Quattrochi et al., 1989; Riddle et al., 1995). This method enables us to target axonal fields in a spatially restricted way, without significant leakage to neighboring areas. After injection, following a survival period to allow axonal transport of retrograde tracers, we observed that cell bodies within $\mathrm{SN}$ accumulated beads in their somata. As shown in a high-power image of the SN, retrogradely transported beads labeled specific neurons in the SN (Fig. 4C) In this example, one vGluT2-negative cell and two vGluT2-positive cells are labeled (Fig. $4 C$, right). A representative injection is shown for the VPL (Fig. 4D). The injected hemisphere of the brain was cut into $50 \mu \mathrm{m}$ sections, and 17 sections were used to determine the location of the injection site (Fig. 4D, left, green), and 21 sections were used to determine the location of the cells labeled by the retrograde beads (Fig. $4 D$, right). The results are summarized with the outlines of the SN shown for each section, and vGluT2-positive labeled cells (red) and vGluT2-negative labeled cells (blue) are shown. For this example, $99 \%$ (825/832 cells, $n=6$ animals) of retrogradely labeled 

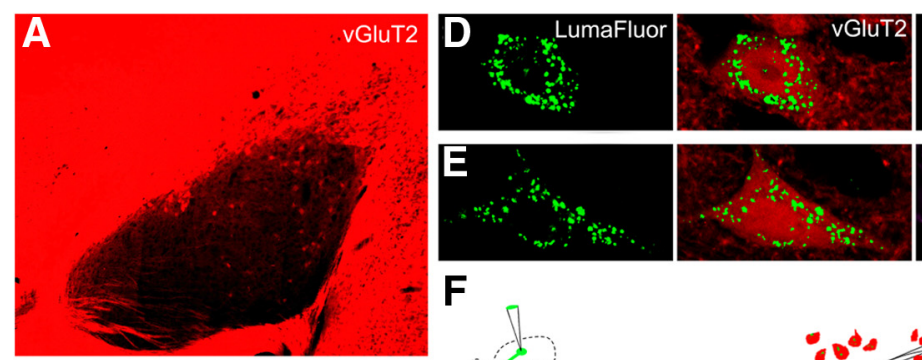

$\mathbf{F}$
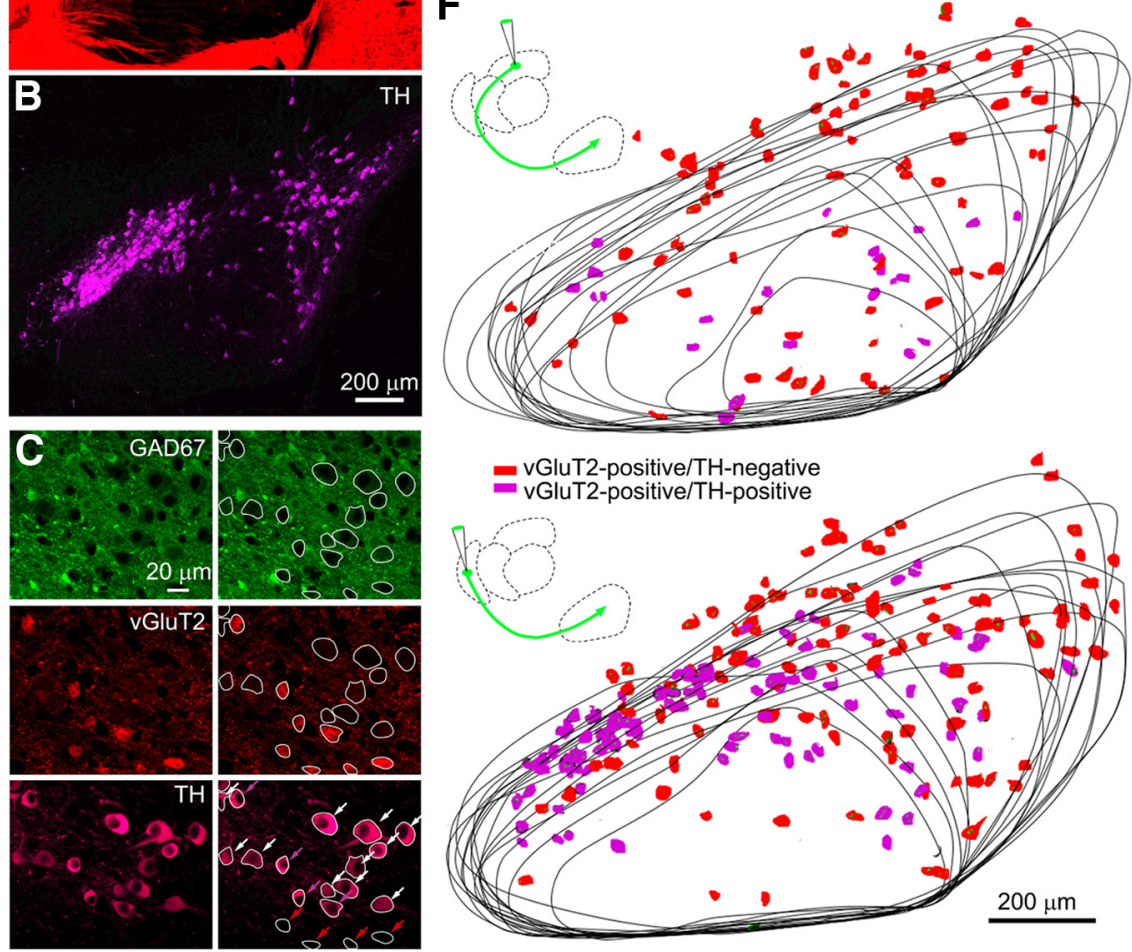

Figure 5. Many of the vGluT2-positive neurons in the SN that project to the nRT and the PTh are dopaminergic. $\boldsymbol{A}$, Fluorescence in a vGluT2-tdTomato mouse. $B$, An antibody to TH (purple) was used to identify dopaminergic neurons in the same preparation as in $\boldsymbol{A}$. C, Fluorescence is shown for a GAD67-GFP::vGluT2-TdTomato mouse stained with a TH antibody. On the right, cells are circled and indicated by arrows (bottom right): vGluT2-positive/TH-negative (red arrows), vGluT2-postitive/TH-positive (purple arrows), and vGluT2-negative/TH-positive (white arrows). $\boldsymbol{D}-\boldsymbol{F}$, Experiments were performed in which fluorescent nanobeads were injected into the thalamus of vGluT2::tdTomato mice stained with a TH antibody. High-power images of two cells labeled with fluorescent nanobeads reveal a vGluT2-positive/TH-negative cell (D) and a vGluT2-positive/TH-positive cell (E). $\boldsymbol{F}$, The location and properties of neurons labeled following thalamic injections is shown.

cells were vGluT2 negative. A similar experiment is shown for an nRT injection (Fig. $4 E$ ). Most of the retrogradely labeled cells were vGluT2 positive $(98 \%, 459$ of 465 cells; $n=6)$. Injections into the PTh also labeled SN neurons, but a mixture of vGlut2positive cells $(51 \%, 97$ of 189 cells; $n=5)$ and vGlut2-negative cells (49\%, 92 of 189 cells; $n=5$ ) were labeled (Fig. 4F).

It remains an open question whether some of the vGluT2positive SN cells that project to the thalamus could also be dopaminergic. The two predominant cell types in the SN are the GABAergic cells of the SNR and the dopaminergic cells of the SNC. In the ventral tegmental area (VTA), some neurons express both $\mathrm{TH}$, which is expressed in dopaminergic cells, and vGluT2, suggesting that they release both dopamine and glutamate (Kawano et al., 2006; Yamaguch et al., 2013). Optical stimulation of ChR2-expressing dopaminergic neurons evoked EPSCs in striatal projection neurons of the nucleus accumbens (Stuber et al., 2010; Tecuapetla et al., 2010) and dorsal striatum (Tritsch et al., 2012) that were eliminated upon genetic ablation of vGluT2 (Stuber et al., 2010; Tritsch et al., 2012). In contrast to the VTA and mesolimbic areas, a prior study (Yamaguchi et al., 2013) suggested that in the SN there is minimal overlap between dopami-
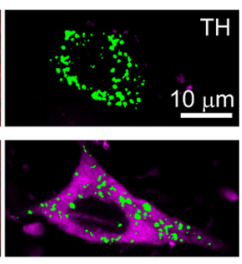

nergic and glutamatergic neurons. They found that vGluT2 is the vesicular transporter required for glutamate release present in the SN (vGluT1 and vGluT3 are not expressed), there are many more $\mathrm{TH}$ expressing neurons than vGluT2-positive neurons in the $\mathrm{SN}(\sim 5: 1)$, and, based on combined in situ hybridization and $\mathrm{TH}$ immunolabeling, the occurrence of $\mathrm{TH}$ positive neurons that also express vGluT2 is rare.

We re-examined $\mathrm{TH}$ expression in the SN using an antibody against $\mathrm{TH}$ to identify dopaminergic neurons (Fig. $5 B$ ) in vGluT2-Cre::tdTomato mice (Fig. 5A). In some experiments, vGluT2-Cre::tdTomato mice were crossed with GAD67-GFP mice. High-power images (Fig. 5C, left) showed that many cell bodies were devoid of green fluorescence (GAD67-GFP negative); some of these cells were vGluT2 positive (red), some cells expressed TH (purple), and some cells expressed both. We analyzed the cells in this image (Fig. 5C, right, cells circled) and found that, of 19 neurons considered, 4 were vGluT2 positive/TH negative (Fig. 5C, bottom right, red arrows), 4 were vGluT2 positive/TH positive (Fig. 5C, bottom right, purple arrows), and 11 were vGluT2 negative/TH positive (Fig. $5 C$, bottom right, white arrows). Using this approach, we analyzed neurons from two mice and found that $16 \%$ of $\mathrm{TH}$ positive cells (171 of 1258 cells) were also vGluT2 positive, and $45 \%$ of vGluT2-positive cells (171 of 362 cells) were also $\mathrm{TH}$ positive. This raises the possibility that some of the vGluT2-positive cells found in the SN also release dopamine, although it is not known which of these cells project to the thalamus.

We therefore examined whether the glutamatergic cells that project to the thalamus are also dopaminergic. After injecting fluorescent retrobeads into either the nRT or the PTh of vGluT2-Cre::tdTomato mice, we determined whether beadlabeled vGluT2-positive cells also expressed TH. High-power images show examples of bead-labeled neurons in the SN following injection into the PTh, with a vGluT2-positive/TH-negative cell (Fig. 5D) and a vGluT2-positive/TH-positive cell (Fig. 5E). Following bead injections into nRT, vGluT2-positive bead-labeled $\mathrm{SN}$ neurons were identified and $\mathrm{TH}$ expression was examined in a series of sections for an nRT injection; vGluT2-positive/THnegative cells (Fig. 5F, red) and vGluT2-positive/TH-positive cells (Fig. $5 F$, purple) were identified. Following nRT injection, $46 \%$ of labeled vGluT2-positive cells (221 of 482 cells; $n=2$ animals) were TH positive. Following a PTh injection (Fig. $5 G$ ), $22 \%$ of labeled vGluT2-positive cells (43 of 193 cells; $n=2$ animals) were $\mathrm{TH}$ positive. These findings indicate that a fraction of the vGluT2-positive cells that project to the thalamus are also dopaminergic.

Thus, functional and anatomical evidence reveals a population of vGluT2-positive SN neurons that provides glutama- 

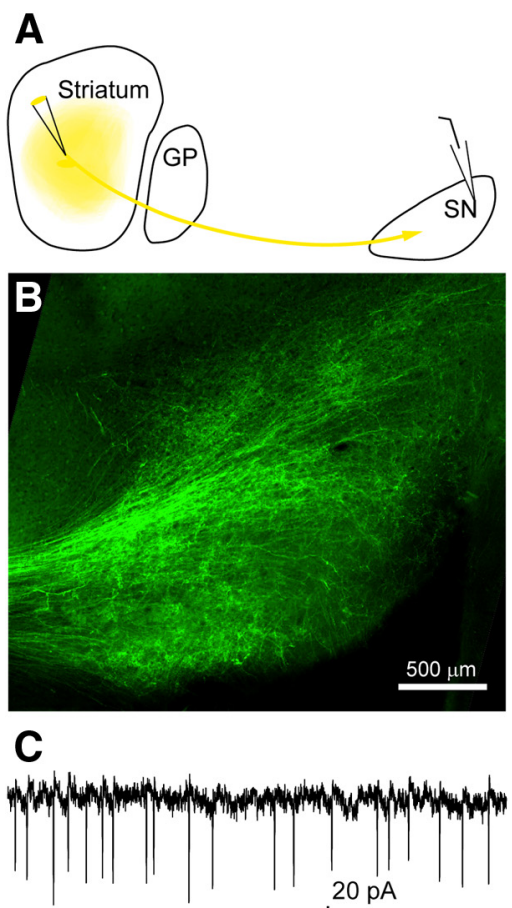

$200 \mathrm{~ms}$

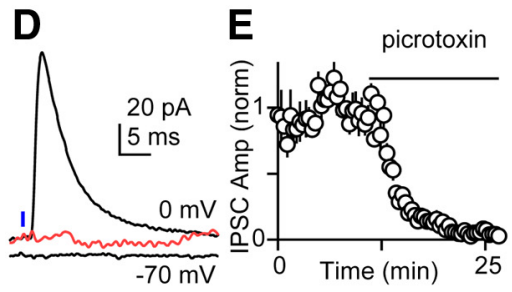

Figure 6. Glutamatergic neurons in the substantia nigra fire spontaneously and receive input from the striatum. $\boldsymbol{A}$, Schematic showing injection of an AAV construct to express ChR2YFP in striatal neurons in a vGluT2-Cre::tdTomato mouse. $\boldsymbol{B}$, YFP labeling of striatal fibers in the SN. C, Example showing spontaneous activity of a vGuT2-positive neuron recorded with an on-cell electrode. The neuron was identified by red fluorescence in a vGuT2-Cre:::tdTomato mouse. D, Example showing whole-cell recording from a vGluT2-positive cell. The IPSC recorded at $0 \mathrm{mV}$ was eliminated by pictrotoxin (red). $\boldsymbol{E}$, Summary of recordings from 10 cells showing the blockade of the IPSC with a $G_{A B A}$ R antagonist.

tergic output from the SN to the nRT and PTh thalamic nuclei. To determine whether these glutamatergic neurons are indeed part of the BG circuit, we tested whether they received input from nuclei within the BG. To determine whether this is the case, we injected an AAV construct into the striatum to express ChR2-YFP, which resulted in labeled fibers projecting to the $\mathrm{SN}$ (Fig. 6A, B). Experiments were performed in vGuT2-Cre: tdTomato mice to allow identification of glutamatergic SN neurons. On-cell recordings (Fig. 6C) showed that vGluT2positive cells were spontaneously active at $7 \pm 1 \mathrm{~Hz}(n=10)$. Optical stimulation of striatal afferents evoked fast IPSCs in these cells $(130 \pm 25 \mathrm{pA}$ at $0 \mathrm{mV}, n=10)$ that were eliminated by picrotoxin, indicating that they were mediated by $\mathrm{GABA}_{\mathrm{A}} \mathrm{Rs}$, the primary neurotransmitter released by striatal projection neurons. These recordings indicate that neurons in the striatum inhibit vGluT2-positive neurons in the SN, and thereby establish that vGluT2-positive neurons in the $\mathrm{SN}$ are part of the circuit that allows the BG to regulate thalamic activity.

\section{Discussion}

Our main finding is that the SN provides an output to the thalamus that has an excitatory component, in addition to the previously described inhibitory component. The output from the SN is highly dependent on the target region: a ventral thalamic area (i.e., VPL) receives GABAergic inhibition, the reticular nucleus receives glutamatergic excitation from vGluT2-positive SN neurons, while select posterior thalamic regions receive a combination of excitation and inhibition.

\section{SN inhibits VPL}

Previous anatomical studies have shown connections of the SN with ventromedial, ventrolateral, ventroanterior, centrolateral, mediodorsal, parafascicular, VPL, anteroventral, and anteromedial thalamic nuclei in the rat, cat, and monkey (Faull and Mehler, 1978; Di Chiara et al., 1979; Beckstead, 1983; Russchen et al., 1987; Ray and Price, 1992; Miyamoto and Jinnai, 1994; Sakai et al., 1998; François et al., 2002; Tsumori et al., 2002; Cebrián et al., 2005; Cebrian and Prensa, 2010). Our study confirms these earlier studies by demonstrating the dense innervation present in the ventral thalamic region. The observation that the $\mathrm{SN}$ inhibits the VPL is also consistent with numerous studies that have established that the net effect of SN activation is the inhibition of relay neurons in the thalamus, and that reductions in the spontaneous firing of SNR neurons result in the reduction of GABA release and the disinhibition of thalamic neurons (Ueki et al., 1977; MacLeod et al., 1980; Timmerman and Westerink, 1997).

\section{SN excites nRT}

Our finding that the $\mathrm{SN} \rightarrow \mathrm{nRT}$ synapse is glutamatergic differs with a previous study that concluded that it is an inhibitory connection (Paré et al., 1990). In that study, they found that SN stimulation led to a pause in the firing of nRT neurons. However, in most of their recordings each pause in spiking was usually preceded by a brief burst of activity. We therefore reinterpret the previous findings as the $\mathrm{SN}$ directly exciting nRT neurons, with subsequent suppression of spiking likely reflecting another process, such as disynaptic inhibition or activation of calciumactivated potassium channels. In cases where no direct excitatory response was observed, disynaptic inhibition could still produce a pause in firing.

The observation that the SN can excite neurons in the nRT is intriguing because these neurons powerfully regulate the activity of many thalamic nuclei. The nRT, a shell-shaped brain structure that consists of GABAergic neurons, is physically located between thalamic relay nuclei and the cortex. nRT neurons receive inputs from thalamic relay nuclei and the cortex but send inhibitory efferents only to thalamocortical relay cells. The simplest interpretation of an excitatory $\mathrm{SN} \rightarrow \mathrm{nRT}$ connection is that the net effect is the inhibition of relay neurons, but it is unlikely that such a simple explanation captures the importance of this connection. Neurons within the nRT are electrically coupled to each other, and populations of these neurons tend to fire together and are involved in the generation of oscillatory activity in the thalamus such as spindle waves (Marks and Roffwarg, 1993; Destexhe et al., 1994; Bazhenov et al., 1999; Landisman et al., 2002). Furthermore, the nRT is divided into different regions, and there is a precise topographic map between distinct regions of the cortex, $\mathrm{nRT}$, and thalamic relay nuclei. It has been hypothesized that the $\mathrm{nRT}$ is involved in attentional modulation, sensory gating, and suppression of distractors (Guillery and Harting, 2003; Pinault, 2004; McAlonan et al., 2006; Zikopoulos and Barbas, 2006, 
2007a,b, 2012; Barbas and Zikopoulos, 2007; Xiao et al., 2009; Ferrarelli and Tononi, 2011; Barbas et al., 2013), and in the preparation and execution of cognitive and motor tasks (Pinault, 2004). We speculate that the excitatory pathway from the SN to the nRT may be involved in selecting a certain task and suppressing other tasks, but future experiments need to be performed to decipher its role.

\section{SN both excites and inhibits PTh}

We found that the SN does not simply inhibit neurons in the PTh. Previously, little was known about the properties of the SN projections to the PTh, which is a group of thalamic nuclei that have been implicated in diverse sensory modalities such as pain, auditory and visual processing (Burton and Jones, 1976), and multisensory and sensorimotor integrations (Hicks and Huerta, 1991; Cappe et al., 2009), and in diverse conditions including migraine and neglect (Kamishina et al., 2008; Kagan et al., 2013). These nuclei are part of segregated cortex-basal ganglia-thalamus loops involved in skeletomotor, oculomotor, cognitive, and limbic functions (Reep et al., 1987, 1994; Sukekawa, 1988; Vargo et al., 1988; Alexander and Crutcher, 1990; Alexander et al., 1991; Aggleton et al., 1995, 1996; Alexinsky, 2001; Haber and Calzavara, 2009; Kamishina et al., 2009). Our findings indicate that the BG provide an output to PTh via two distinct SN neuron populations: GABAergic neurons and glutamatergic neurons. The involvement of an excitatory $\mathrm{SN} \rightarrow \mathrm{PTh}$ connection was unexpected and a major departure from the prevailing view in which thalamic activity is regulated by the firing rate of spontaneously active inhibitory SN neurons. These findings suggest that it is the balance of excitation and inhibition provided by the SN-PTh connection that will dictate the effect of the BG on the activity of this thalamic region.

\section{Synaptic activation of glutamatergic neurons of the $\mathrm{SN}$}

We have found that the vGluT2-positive neurons of the SN are inhibited by direct projections from striatal neurons. This establishes that these neurons are innervated by other neurons of the $B G$, and therefore they are indeed output neurons of the BG circuitry. Future studies will help to clarify whether glutamatergic SN neurons are differentially activated compared with inhibitory neurons of the SNR, and whether they are differentially recruited by direct, indirect, and hyperdirect BG pathways.

\section{Some $\mathrm{SN} \rightarrow$ thalamus neurons release both glutamate and dopamine}

Although there is precedent for dopaminergic neurons releasing glutamate, it was somewhat surprising that many of the glutamatergic neurons that project to the thalamus are also TH positive. A prior study (Yamaguchi et al., 2013) suggested that in the SN there is minimal overlap between dopaminergic and glutamatergic neurons, in contrast to the VTA, where neurons express both TH and vGluT2 (Kawano et al., 2006; Yamaguch et al., 2011). We find that most dopaminergic neurons in the $\mathrm{SN}$ are not glutamatergic, and many of the glutamatergic neurons that project to the PTh and the nRT do not express TH. Nonetheless, our observation that some of thalamus-projecting vGluT2positive $\mathrm{SN}$ neurons are also $\mathrm{TH}$ positive suggests that many of the SN neurons innervating $\mathrm{nRT}$ and PTh release both glutamate and dopamine.

Previous studies examined the role of glutamatergic signaling from dopaminergic neurons by conditionally deleting vGuT2 from dopaminergic neurons (Birgner et al., 2010; Alsio et al., 2011; Tritsch et al., 2012). They found altered locomotion in response to amphetamine (Birgner et al., 2010), decreased dopamine release, and abnormal reward-seeking behavior (Alsio et al., 2011). Our findings suggest that glutamatergic transmission by dopaminergic neurons projecting from the SN to the thalamus could contribute to these previously described behavioral deficits and could have other behavioral consequences.

\section{Implications for disease}

Our finding that $\mathrm{SN}$ provides glutamatergic output to a region of the thalamus involved in sensorimotor processing may have important implications for neurodegenerative motor disorders such as Parkinson's disease. It has been suggested that a reactive increase in glutamate transmission occurs in the parkinsonian state (Robelet et al., 2004) and that increased glutamatergic transmission may contribute to degeneration in the SNC (Przedborski, 2005). A number of studies have found anti-parkinsonian effects of AMPA, NMDA, and metabotropic glutamate receptor antagonists, both alone and in combination with dopaminergic therapies (Klockgether and Turski, 1990; Klockgether et al., 1991; Löschmann et al., 1991; Engber et al., 1994; Gossel et al., 1995; Maj et al., 1995; Marti et al., 2003; Levandis et al., 2008; Samadi et al., 2008). The glutamatergic output from the SN to the thalamus that we describe here may be the target of glutamate receptor antagonists in the treatment of Parkinson's disease. More generally, the glutamatergic connection between the BG and the thalamus that we have identified must be incorporated into current concepts of normal and pathological function of basal ganglia and thalamus.

\section{References}

Adamantidis AR, Tsai HC, Boutrel B, Zhang F, Stuber GD, Budygin EA, Touriño C, Bonci A, Deisseroth K, de Lecea L (2011) Optogenetic interrogation of dopaminergic modulation of the multiple phases of rewardseeking behavior. J Neurosci 31:10829-10835. CrossRef Medline

Aggleton JP, Neave N, Nagle S, Sahgal A (1995) A comparison of the effects of medial prefrontal, cingulate cortex, and cingulum bundle lesions on tests of spatial memory: evidence of a double dissociation between frontal and cingulum bundle contributions. J Neurosci 15:7270-7281. Medline

Aggleton JP, Hunt PR, Nagle S, Neave N (1996) The effects of selective lesions within the anterior thalamic nuclei on spatial memory in the rat. Behav Brain Res 81:189-198. CrossRef Medline

Alexander GE, Crutcher MD (1990) Functional architecture of basal ganglia circuits: neural substrates of parallel processing. Trends Neurosci 13:266271. CrossRef Medline

Alexander GE, Crutcher MD, DeLong MR (1991) Basal ganglia-thalamocortical circuits: parallel substrates for motor, oculomotor, "prefrontal" and "limbic" functions. In: The prefrontal cortex: its structure, function and pathology; Progress in Brain Research (Uylings HBM, ed), pp 119-146. New York: Elsevier.

Alexinsky T (2001) Differential effect of thalamic and cortical lesions on memory systems in the rat. Behav Brain Res 122:175-191. CrossRef Medline

Alsio J, Nordenankar K, Arvidsson E, Birgner C, Mahmoudi S, Halbout B, Smith C, Fortin GM, Olson L, Descarries L, Trudeau LE, Kullander K, Levesque D, Wallen-Mackenzie A (2011) Enhanced sucrose and cocaine self-administration and cue-induced drug seeking after loss of VGLUT2 in midbrain dopamine neurons in mice. J Neurosci 31:12593-12603. CrossRef Medline

Barbas H, Zikopoulos B (2007) The prefrontal cortex and flexible behavior. Neuroscientist 13:532-545. CrossRef Medline

Barbas H, García-Cabezas MÁ, Zikopoulos B (2013) Frontal-thalamic circuits associated with language. Brain Lang 126:49-61. CrossRef Medline

Bateup HS, Santini E, Shen W, Birnbaum S, Valjent E, Surmeier DJ, Fisone G, Nestler EJ, Greengard P (2010) Distinct subclasses of medium spiny neurons differentially regulate striatal motor behaviors. Proc Natl Acad Sci U S A 107:14845-14850. CrossRef Medline

Bazhenov M, Timofeev I, Steriade M, Sejnowski TJ (1999) Self-sustained rhythmic activity in the thalamic reticular nucleus mediated by depolarizing GABAA receptor potentials. Nat Neurosci 2:168-174. CrossRef Medline

Beckstead RM (1983) Long collateral branches of substantia nigra pars reticulata axons to thalamus, superior colliculus and reticular formation in 
monkey and cat. Multiple retrograde neuronal labeling with fluorescent dyes. Neuroscience 10:767-779. CrossRef Medline

Berényi A, Gombköto P, Farkas A, Paróczy Z, Márkus Z, Averkin RG, Benedek G, Nagy A (2009) How moving visual stimuli modulate the activity of the substantia nigra pars reticulata. Neuroscience 163:13161326. CrossRef Medline

Birgner C, Nordenankar K, Lundblad M, Mendez JA, Smith C, le Greves M, Galter D, Olson L, Fredriksson A, Trudeau LE, Kullander K, WallenMackenzie A VGLUT2 in dopamine neurons is required for psychostimulantinduced behavioral activation. Proc Natl Acad Sci U S A 107:389-394. CrossRef Medline

Bolam JP, Hanley JJ, Booth PA, Bevan MD (2000) Synaptic organisation of the basal ganglia. J Anat 196:527-542. CrossRef Medline

Burton H, Jones EG (1976) The posterior thalamic region and its cortical projection in new world and old world monkeys. J Comp Neurol 168: 249-301. CrossRef Medline

Cappe C, Morel A, Barone P, Rouiller EM (2009) The thalamocortical projection systems in primate: an anatomical support for multisensory and sensorimotor interplay. Cereb Cortex 19:2025-2037. CrossRef Medline

Cebrián C, Prensa L (2010) Basal ganglia and thalamic input from neurons located within the ventral tier cell cluster region of the substantia nigra pars compacta in the rat. J Comp Neurol 518:1283-1300. CrossRef Medline

Cebrián C, Parent A, Prensa L (2005) Patterns of axonal branching of neurons of the substantia nigra pars reticulata and pars lateralis in the rat. J Comp Neurol 492:349-369. CrossRef Medline

Chevalier G, Deniau JM (1984) Spatio-temporal organization of a branched tecto-spinal/tecto-diencephalic neuronal system. Neuroscience 12:427439. CrossRef Medline

Chevalier G, Deniau JM (1990) Disinhibition as a basic process in the expression of striatal functions. Trends Neurosci 13:277-280. CrossRef Medline

Chevalier G, Vacher S, Deniau JM, Desban M (1985) Disinhibition as a basic process in the expression of striatal functions. I. The striato-nigral influence on tecto-spinal/tecto-diencephalic neurons. Brain Res 334:215-226. CrossRef Medline

Daubaras M, Dal Bo G, Flores C (2014) Target-dependent expression of the netrin-1 receptor, UNC5C, in projection neurons of the ventral tegmental area. Neuroscience 260:36-46. CrossRef Medline

DeLong MR, Wichmann T (2007) Circuits and circuit disorders of the basal ganglia. Arch Neurol 64:20-24. CrossRef Medline

Deniau JM, Mailly P, Maurice N, Charpier S (2007) The pars reticulata of the substantia nigra: a window to basal ganglia output. Prog Brain Res 160:151-172. CrossRef Medline

Destexhe A, Contreras D, Sejnowski TJ, Steriade M (1994) A model of spindle rhythmicity in the isolated thalamic reticular nucleus. J Neurophysiol 72:803-818. Medline

Deutch AY, Goldstein M, Roth RH (1986) The ascending projections of the dopaminergic neurons of the substantia nigra, zona reticulata: a combined retrograde tracer-immunohistochemical study. Neurosci Lett 71: 257-263. CrossRef Medline

Di Chiara G, Porceddu ML, Morelli M, Mulas ML, Gessa GL (1979) Evidence for a GABAergic projection from the substantia nigra to the ventromedial thalamus and to the superior colliculus of the rat. Brain Res 176:273-284. CrossRef Medline

Doupe AJ, Perkel DJ, Reiner A, Stern EA (2005) Birdbrains could teach basal ganglia research a new song. Trends Neurosci 28:353-363. CrossRef Medline

Engber TM, Papa SM, Boldry RC, Chase TN (1994) NMDA receptor blockade reverses motor response alterations induced by levodopa. Neuroreport 5:2586-2588. CrossRef Medline

Eyre MD, Antal M, Nusser Z (2008) Distinct deep short-axon cell subtypes of the main olfactory bulb provide novel intrabulbar and extrabulbar GABAergic connections. J Neurosci 28:8217-8229. CrossRef Medline

Faull RL, Mehler WR (1978) The cells of origin of nigrotectal, nigrothalamic and nigrostriatal projections in the rat. Neuroscience 3:989-1002. CrossRef Medline

Ferrarelli F, Tononi G (2011) The thalamic reticular nucleus and schizophrenia. Schizophr Bull 37:306-315. CrossRef Medline

François C, Tande D, Yelnik J, Hirsch EC (2002) Distribution and morphology of nigral axons projecting to the thalamus in primates. J Comp Neurol 447:249-260. CrossRef Medline

Fremeau RT Jr, Troyer MD, Pahner I, Nygaard GO, Tran CH, Reimer RJ, Bellocchio EE, Fortin D, Storm-Mathisen J, Edwards RH (2001) The expression of vesicular glutamate transporters defines two classes of excitatory synapse. Neuron 31:247-260. CrossRef Medline

Gittis AH, Nelson AB, Thwin MT, Palop JJ, Kreitzer AC (2010) Distinct roles of GABAergic interneurons in the regulation of striatal output pathways. J Neurosci 30:2223-2234. CrossRef Medline

Gong S, Zheng C, Doughty ML, Losos K, Didkovsky N, Schambra UB, Nowak NJ, Joyner A, Leblanc G, Hatten ME, Heintz N (2003) A gene expression atlas of the central nervous system based on bacterial artificial chromosomes. Nature 425:917-925. CrossRef Medline

Gong S, Doughty M, Harbaugh CR, Cummins A, Hatten ME, Heintz N, Gerfen CR (2007) Targeting Cre recombinase to specific neuron populations with bacterial artificial chromosome constructs. J Neurosci 27: 9817-9823. CrossRef Medline

Gossel M, Schmidt WJ, Löscher W, Zajaczkowski W, Danysz W (1995) Effect of coadministration of glutamate receptor antagonists and dopaminergic agonists on locomotion in monoamine-depleted rats. J Neural Transm Park Dis Dement Sect 10:27-39. CrossRef Medline

Gould E, Butcher LL (1986) Cholinergic neurons in the rat substantia nigra. Neurosci Lett 63:315-319. CrossRef Medline

Grueter BA, Rothwell PE, Malenka RC (2012) Integrating synaptic plasticity and striatal circuit function in addiction. Curr Opin Neurobiol 22:545551. CrossRef Medline

Guillery RW, Harting JK (2003) Structure and connections of the thalamic reticular nucleus: advancing views over half a century. J Comp Neurol 463:360-371. CrossRef Medline

Haber SN, Calzavara R (2009) The cortico-basal ganglia integrative network: the role of the thalamus. Brain Res Bull 78:69-74. CrossRef Medline

Hauber W (1998) Involvement of basal ganglia transmitter systems in movement initiation. Prog Neurobiol 56:507-540. CrossRef Medline

Hicks RR, Huerta MF (1991) Differential thalamic connectivity of rostral and caudal parts of cortical area Fr2 in rats. Brain Res 568:325-329. CrossRef Medline

Jin X, Costa RM (2010) Start/stop signals emerge in nigrostriatal circuits during sequence learning. Nature 466:457-462. CrossRef Medline

Joel D, Weiner I (1994) The organization of the basal gangliathalamocortical circuits: open interconnected rather than closed segregated. Neuroscience 63:363-379. CrossRef Medline

Kagan R, Kainz V, Burstein R, Noseda R (2013) Hypothalamic and basal ganglia projections to the posterior thalamus: possible role in modulation of migraine headache and photophobia. Neuroscience 248C:359-368. CrossRef Medline

Kamishina H, Yurcisin GH, Corwin JV, Reep RL (2008) Striatal projections from the rat lateral posterior thalamic nucleus. Brain Res 1204:24-39. CrossRef Medline

Kamishina H, Conte WL, Patel SS, Tai RJ, Corwin JV, Reep RL (2009) Cortical connections of the rat lateral posterior thalamic nucleus. Brain Res 1264:39-56. CrossRef Medline

Katz LC, Burkhalter A, Dreyer WJ (1984) Fluorescent latex microspheres as a retrograde neuronal marker for in vivo and in vitro studies of visual cortex. Nature 310:498-500. CrossRef Medline

Kawano M, Kawasaki A, Sakata-Haga H, Fukui Y, Kawano H, Nogami H, Hisano S (2006) Particular subpopulations of midbrain and hypothalamic dopamine neurons express vesicular glutamate transporter 2 in the rat brain. J Comp Neurol 498:581-592. CrossRef Medline

Kha HT, Finkelstein DI, Tomas D, Drago J, Pow DV, Horne MK (2001) Projections from the substantia nigra pars reticulata to the motor thalamus of the rat: single axon reconstructions and immunohistochemical study. J Comp Neurol 440:20-30. CrossRef Medline

Kilpatrick IC, Starr MS, Fletcher A, James TA, MacLeod NK (1980) Evidence for a GABAergic nigrothalamic pathway in the rat. Exp Brain Res 40:45. Medline

Klockgether T, Turski L (1990) NMDA antagonists potentiate antiparkinsonian actions of L-dopa in monoamine-depleted rats. Ann Neurol 28: 539-546. CrossRef Medline

Klockgether T, Turski L, Honoré T, Zhang ZM, Gash DM, Kurlan R, Greenamyre JT (1991) The AMPA receptor antagonist NBQX has antiparkinsonian effects in monoamine-depleted rats and MPTP-treated monkeys. Ann Neurol 30:717-723. CrossRef Medline

Kravitz AV, Freeze BS, Parker PR, Kay K, Thwin MT, Deisseroth K, Kreitzer AC (2010) Regulation of parkinsonian motor behaviours by optogenetic control of basal ganglia circuitry. Nature 466:622-626. CrossRef Medline

Lammel S, Hetzel A, Häckel O, Jones I, Liss B, Roeper J (2008) Unique 
properties of mesoprefrontal neurons within a dual mesocorticolimbic dopamine system. Neuron 57:760-773. CrossRef Medline

Landisman CE, Long MA, Beierlein M, Deans MR, Paul DL, Connors BW (2002) Electrical synapses in the thalamic reticular nucleus. J Neurosci 22:1002-1009. Medline

Lavin A, Grace AA (1998) Dopamine modulates the responsivity of mediodorsal thalamic cells recorded in vitro. J Neurosci 18:10566-10578. Medline

Leblois A, Bodor AL, Person AL, Perkel DJ (2009) Millisecond timescale disinhibition mediates fast information transmission through an avian basal ganglia loop. J Neurosci 29:15420-15433. CrossRef Medline

Levandis G, Bazzini E, Armentero MT, Nappi G, Blandini F (2008) Systemic administration of an mGluR5 antagonist, but not unilateral subthalamic lesion, counteracts 1-DOPA-induced dyskinesias in a rodent model of Parkinson's disease. Neurobiol Dis 29:161-168. CrossRef Medline

Löschmann PA, Lange KW, Kunow M, Rettig KJ, Jähnig P, Honoré T, Turski L, Wachtel H, Jenner P, Marsden CD (1991) Synergism of the AMPAantagonist NBQX and the NMDA-antagonist CPP with L-dopa in models of Parkinson's disease. J Neural Transm Park Dis Dement Sect 3:203-213. CrossRef Medline

MacLeod NK, James TA, Kilpatrick IC, Starr MS (1980) Evidence for a GABAergic nigrothalamic pathway in the rat. II. Electrophysiological studies. Exp Brain Res 40:55-61. Medline

Maj J, Rogoz Z, Skuza G, Kolodziejczyk K (1995) Some central effects of GYKI 52466, a non-competitive AMPA receptor antagonist. Polish J Pharmacol 47:501-507.

Marks GA, Roffwarg HP (1993) Spontaneous activity in the thalamic reticular nucleus during the sleep/wake cycle of the freely-moving rat. Brain Res 623:241-248. CrossRef Medline

Marti M, Paganini F, Stocchi S, Mela F, Beani L, Bianchi C, Morari M (2003) Plasticity of glutamatergic control of striatal acetylcholine release in experimental parkinsonism: opposite changes at group-II metabotropic and NMDA receptors. J Neurochem 84:792-802. CrossRef Medline

McAlonan K, Cavanaugh J, Wurtz RH (2006) Attentional modulation of thalamic reticular neurons. J Neurosci 26:4444-4450. CrossRef Medline

Miyamoto Y, Jinnai K (1994) The inhibitory input from the substantia nigra to the mediodorsal nucleus neurons projecting to the prefrontal cortex in the cat. Brain Res 649:313-318. CrossRef Medline

Oertel WH, Mugnaini E (1984) Immunocytochemical studies of GABAergic neurons in rat basal ganglia and their relations to other neuronal systems. Neurosci Lett 47:233-238. CrossRef Medline

Packard MG, Knowlton BJ (2002) Learning and memory functions of the basal ganglia. Annu Rev Neurosci 25:563-593. CrossRef Medline

Paré D, Hazrati LN, Parent A, Steriade M (1990) Substantia nigra pars reticulata projects to the reticular thalamic nucleus of the cat: a morphological and electrophysiological study. Brain Res 535:139-146. CrossRef Medline

Pascoli V, Turiault M, Lüscher C (2012) Reversal of cocaine-evoked synaptic potentiation resets drug-induced adaptive behaviour. Nature 481:7175. CrossRef Medline

Person AL, Perkel DJ (2005) Unitary IPSPs drive precise thalamic spiking in a circuit required for learning. Neuron 46:129-140. CrossRef Medline

Pinault D (2004) The thalamic reticular nucleus: structure, function and concept. Brain Res Brain Res Rev 46:1-31. CrossRef Medline

Przedborski S (2005) Pathogenesis of nigral cell death in Parkinson's disease. Parkinsonism Relat Disord 11 [Suppl 1]:S3-S7. CrossRef Medline

Quattrochi JJ, Mamelak AN, Madison RD, Macklis JD, Hobson JA (1989) Mapping neuronal inputs to REM sleep induction sites with carbacholfluorescent microspheres. Science 245:984-986. CrossRef Medline

Rajakumar N, Elisevich K, Flumerfelt BA (1994) Parvalbumin-containing GABAergic neurons in the basal ganglia output system of the rat. J Comp Neurol 350:324-336. CrossRef Medline

Ray JP, Price JL (1992) The organization of the thalamocortical connections of the mediodorsal thalamic nucleus in the rat, related to the ventral forebrain-prefrontal cortex topography. J Comp Neurol 323:167-197. CrossRef Medline

Reep RL, Corwin JV, Hashimoto A, Watson RT (1987) Efferent connections of the rostral portion of medial agranular cortex in rats. Brain Res Bull 19:203-221. CrossRef Medline

Reep RL, Chandler HC, King V, Corwin JV (1994) Rat posterior parietal cortex: topography of corticocortical and thalamic connections. Exp Brain Res 100:67-84. CrossRef Medline

Riddle DR, Lo DC, Katz LC (1995) NT-4-mediated rescue of lateral genic- ulate neurons from effects of monocular deprivation. Nature 378:189191. CrossRef Medline

Robelet S, Melon C, Guillet B, Salin P, Kerkerian-Le Goff L (2004) Chronic L-DOPA treatment increases extracellular glutamate levels and GLT1 expression in the basal ganglia in a rat model of Parkinson's disease. Eur J Neurosci 20:1255-1266. CrossRef Medline

Russchen FT, Amaral DG, Price JL (1987) The afferent input to the magnocellular division of the mediodorsal thalamic nucleus in the monkey, Macaca fascicularis. J Comp Neurol 256:175-210. CrossRef Medline

Sakai ST, Grofova I, Bruce K (1998) Nigrothalamic projections and nigrothalamocortical pathway to the medial agranular cortex in the rat: single- and double-labeling light and electron microscopic studies. J Comp Neurol 391:506-525. CrossRef Medline

Samadi P, Grégoire L, Morissette M, Calon F, Hadj Tahar A, Dridi M, Belanger N, Meltzer LT, Bédard PJ, Di Paolo T (2008) mGluR5 metabotropic glutamate receptors and dyskinesias in MPTP monkeys. Neurobiol Aging 29:1040-1051. CrossRef Medline

Sánchez-González MA, García-Cabezas MA, Rico B, Cavada C (2005) The primate thalamus is a key target for brain dopamine. J Neurosci 25:60766083. CrossRef Medline

Schmidt R, Leventhal DK, Mallet N, Chen F, Berke JD (2013) Canceling actions involves a race between basal ganglia pathways. Nat Neurosci 16:1118-1124. CrossRef Medline

Silkis I (2001) The cortico-basal ganglia-thalamocortical circuit with synaptic plasticity. II. Mechanism of synergistic modulation of thalamic activity via the direct and indirect pathways through the basal ganglia. Biosystems 59:7-14. CrossRef Medline

Smith AD, Bolam JP (1990) The neural network of the basal ganglia as revealed by the study of synaptic connections of identified neurones. Trends Neurosci 13:259-265. CrossRef Medline

Sridharan D, Prashanth PS, Chakravarthy VS (2006) The role of the basal ganglia in exploration in a neural model based on reinforcement learning. Int J Neural Syst 16:111-124. CrossRef Medline

Stuber GD, Hnasko TS, Britt JP, Edwards RH, Bonci A (2010) Dopaminergic terminals in the nucleus accumbens but not the dorsal striatum corelease glutamate. J Neurosci 30:8229-8233. CrossRef Medline

Sukekawa K (1988) Reciprocal connections between medial prefrontal cortex and lateral posterior nucleus in rats. Brain Behav Evol 32:246-251. CrossRef Medline

Tamamaki N, Yanagawa Y, Tomioka R, Miyazaki J, Obata K, Kaneko T (2003) Green fluorescent protein expression and colocalization with calretinin, parvalbumin, and somatostatin in the GAD67-GFP knock-in mouse. J Comp Neurol 467:60-79. CrossRef Medline

Tecuapetla F, Patel JC, Xenias H, English D, Tadros I, Shah F, Berlin J, Deisseroth K, Rice ME, Tepper JM, Koos T (2010) Glutamatergic signaling by mesolimbic dopamine neurons in the nucleus accumbens. J Neurosci 30:7105-7110. CrossRef Medline

Timmerman W, Westerink BH (1997) Electrical stimulation of the substantia nigra reticulata: detection of neuronal extracellular GABA in the ventromedial thalamus and its regulatory mechanism using microdialysis in awake rats. Synapse (New York) 26:62-71. CrossRef Medline

Tritsch NX, Sabatini BL (2012) Dopaminergic modulation of synaptic transmission in cortex and striatum. Neuron 76:33-50. CrossRef Medline

Tsumori T, Yokota S, Ono K, Yasui Y (2002) Synaptic organization of GABAergic projections from the substantia nigra pars reticulata and the reticular thalamic nucleus to the parafascicular thalamic nucleus in the rat. Brain Res 957:231-241. CrossRef Medline

Ueki A, Uno M, Anderson M, Yoshida M (1977) Monosynaptic inhibition of thalamic neurons produced by stimulation of the substantia nigra. Experientia 33:1480-1482. CrossRef Medline

Vargo JM, Corwin JV, King V, Reep RL (1988) Hemispheric asymmetry in neglect produced by unilateral lesions of dorsomedial prefrontal cortex in rats. Exp Neurol 102:199-209. CrossRef Medline

Vong L, Ye C, Yang Z, Choi B, Chua S Jr, Lowell BB (2011) Leptin action on GABAergic neurons prevents obesity and reduces inhibitory tone to POMC neurons. Neuron 71:142-154. CrossRef Medline

Wichmann T, DeLong MR (2007) Anatomy and physiology of the basal ganglia: relevance to Parkinson's disease and related disorders. In: Handbook of clinical neurology (Aminoff MJ, Boller F, Swaab DF, Koller WC, Melamed E, eds.), pp. 1, 3-18. New York: Elsevier.

Witten IB, Lin SC, Brodsky M, Prakash R, Diester I, Anikeeva P, Gradinaru V, Ramakrishnan C, Deisseroth K (2010) Cholinergic interneurons con- 
trol local circuit activity and cocaine conditioning. Science 330:16771681. CrossRef Medline

Xiao D, Zikopoulos B, Barbas H (2009) Laminar and modular organization of prefrontal projections to multiple thalamic nuclei. Neuroscience 161: 1067-1081. CrossRef Medline

Yagüe JG, Cavaccini A, Errington AC, Crunelli V, Di Giovanni G (2013) Dopaminergic modulation of tonic but not phasic GABAA-receptormediated current in the ventrobasal thalamus of Wistar and GAERS rats. Exp Neurol 247:1-7. CrossRef Medline

Yamaguchi T, Wang HL, Morales M (2013) Glutamate neurons in the substantia nigra compacta and retrorubral field. Eur J Neurosci 38:36023610. CrossRef Medline

Yung KK, Kwok KH, Gao ZG, Choi SY, Kwok FS (1998) Expression of
GABA transaminase immunoreactivity in interneurons of the rat neostriatum. Neurochem Int 33:567-572. CrossRef Medline

Zikopoulos B, Barbas H (2006) Prefrontal projections to the thalamic reticular nucleus form a unique circuit for attentional mechanisms. J Neurosci 26:7348-7361. CrossRef Medline

Zikopoulos B, Barbas H (2007a) Circuits formultisensory integration and attentional modulation through the prefrontal cortex and the thalamic reticular nucleus in primates. Rev Neurosci 18:417-438. Medline

Zikopoulos B, Barbas H (2007b) Parallel driving and modulatory pathways link the prefrontal cortex and thalamus. PLoS One 2:e848. CrossRef Medline

Zikopoulos B, Barbas H (2012) Pathways for emotions and attention converge on the thalamic reticular nucleus in primates. J Neurosci 32:53385350. CrossRef Medline 